\title{
PCR-based Single-strand Conformation Polymorphism (SSCP) Analysis to Clone Nine Aquaporin Genes in Cucumber
}

\author{
Jiahua Xie, ${ }^{1}$ Todd C. Wehner, ${ }^{2}$ and Mark A. Conkling ${ }^{3}$ \\ Departments of Horticultural Science and Genetics, North Carolina State University, Raleigh, NC 27695
}

\begin{abstract}
AdDitional INDEX words. Cucumis sativus, gene cloning, PCR-SSCP
Abstract. Combining the use of PCR and single-strand conformation polymorphisms (SSCP), nine sequences from the cucumber genome were successfully identified and cloned that encoded two well-conserved asparagine-proline-alanine (NPA) domain homologues to aquaporin genes. The sensitivity and detection efficiency of SSCP and restriction enzyme analysis for detecting DNA sequence variation were evaluated using similar-sized DNA fragments. The SSCP analysis was more sensitive and efficient for discriminating different clones than restriction enzyme analysis, although some sequence variation inside similar-sized DNA fragments could be identified by restriction analysis. Consideration of the results of SSCP analysis with DNA sequence information indicated that one or two base pair changes in the amplified regions could be detected. Moreover, the SSCP analysis results of genomic DNA PCR products that were amplified by degenerate primers can provide rough information about the number of member genes. If the SSCP bands of a cloned fragment (such as CRB7) did not have the corresponding bands from genomic DNA PCR products, that fragment might be a misamplified product. The PCR-based SSCP method with degenerate oligonucleotide primers should facilitate the cloning of member genes.
\end{abstract}

The polymerase chain reaction (PCR) using degenerate oligonucleotide primers has made it possible to clone genes more quickly and easily (Takumi and Lodish, 1994; You and Scholl, 1998). With the accumulation of gene sequences, it becomes easy to design the degenerate primers for cloning new members of a gene family from related species. However, for members of a gene family amplified using degenerate primers, the PCR products for these genes can be similar in length. Thus, the different genes will be hidden when they are run on an agarose gel. Direct DNA sequencing would be the best method for distinguishing different DNA fragments, and sequencing as many clones as possible may permit the identification of some or all members of a gene family, but it is time-consuming and expensive.

After cloning, different restriction enzymes that cut DNA infrequently are used to identify the new homologue, especially if using enzymes with recognition sites of 6 to 8 bp (Preston, 1993). The problem is that restriction analysis for small (300 to $500 \mathrm{bp}$ ) DNA bands requires that the bands have a recognition site close to the middle. DNA bands without enzyme recognition sites, or with two outside recognition sites may not appear in the analysis. Therefore, a more sensitive method is needed for detection of DNA fragments of similar length to identify the member genes during cloning.

Single-strand conformation polymorphisms (SSCP) are based on electrophoretic detection of conformational changes in singlestranded DNA molecules resulting from point mutations or other forms of small nucleotide changes. It was originally developed

Received for publication 1 May 2002. Accepted for publication 2 Sept. 2002. The use of trade names in this publication does not imply endorsement by the North Carolina Agricultural Research Service (NCARS), Raleigh, NC 27695-7643 of the products named, or criticism of similar ones not mentioned. This work was supported by a grant from Pickle Packers International. The authors gratefully acknowledge the technical assistance of J.P. Fellers, Y. Li, G.N. Acedo, and W.L. Liu.

${ }^{1}$ Postdoctoral research associate. Currently researcher, Vector Tobacco Ltd., 700 Main Street, Durham, NC 27701.

2Professor and corresponding author; email Todd_Wehner@NCSU.edu.

${ }^{3}$ Professor. Currently vice president, Vector Tobacco Ltd., 700 Main Street, Durham, NC 27701 for rapid analysis of mutations (Orita et al., 1989). Single-strand conformation polymorphisms has been used extensively in human genetics to detect mutations within genes, and was able to detect single-point mutations (Hayashi, 1992). Single-strand conformation polymorphisms analysis was considered as a sensitive, inexpensive, and rapid method for detecting sequence variation (Sekiya, 1993; Slabaugh et al., 1997). This technique was also employed to characterize expressed products between two highly related member genes (Hedley et al., 1994), analyze the difference among members of a gene family (Hagiwara et al., 1998; Slabaugh et al., 1997), and produce SSCP markers for gene mapping (Slabaugh et al., 1997). Recently, the usefulness of this approach has been extended through the use of end-labeled primers and PCR amplification, with a small amount of genomic DNA or RNA being analyzed (Peterson et al., 1995; Slabaugh et al., 1997).

Aquaporins (AQPs) are a family of intrinsic membrane proteins with many homologous genes that function as water-selective channels in the plasma membranes of many water-transporting tissues (Agre et al., 1993). We needed to identify a rootspecific aquaporin gene in cucumber for our root-knot nematode resistance work. Using PCR-based SSCP analysis, nine sequences have been successfully cloned from the cucumber genome that encoded two well-conserved NPA domains homologous to the aquaporin gene.

\section{Materials and Methods}

DNA PREPaRATION. Seedlings of Cucumis sativus L. 'Sumter', a monoecious inbred pickling cucumber, were grown in the greenhouse. Leaves of four-week-old seedlings were harvested for DNA isolation. Total DNA was prepared by grinding frozen leaf tissue and suspending the powder in CTAB buffer containing 50 mм EDTA, 10 mм Tris- $\mathrm{HCl}$ (pH 8.0), 1\% CTAB, 0.7 м NaCl, and $0.2 \% \beta$-mercaptoethanol. DNA was precipitated by ice-cold $100 \%$ iso-propanol, and then washed with $76 \%$ ethanol with 0.2 м NaOAc and $76 \%$ ethanol with $10 \mathrm{~mm} \mathrm{NH}_{4} \mathrm{OAc}$, respectively.

SYNTHESIS OF OLIGONUCLEOTIDE PRIMERS. Multiple alignments 
of the most highly conserved portions of 52 major intrinsic protein (MIP) family proteins showed that there were the two well-conserved NPA motifs in their amino acid sequence (Park and Saier, 1996). Two degenerate primers were designed based on amino acid sequence of the two well-conserved NPA motifs. Twenty base pair forward primer Cu $15^{\prime}$ [5'-GG(A/T/C/G)-CACATC-AA(C/T)-CC(A/T/C/G)-GC(A/T/C/G)-GT-3'], based on the amino acid sequence GHINPAV, and $20 \mathrm{bp}$ reverse primer Cu2 3' [5'-ACT-GG(A/T/C/G)-ATC-AA(C/T)-CCA-GC(A/T/ C/G)-AG-3'], based upon the amino acid sequence TGINPAR, were synthesized (Genosys Biotechnologies Inc, The Woodlands, Texas).

END LABELING OF OLIGONUCLEOTIDE PRIMERS. The $5 \mu \mathrm{g}$ of each primer $\mathrm{Cu} 1$ and $\mathrm{Cu} 2$ were end-labeled with $\gamma-{ }^{32} \mathrm{P}$ dATP. Twenty microliters of reaction solution contained $1 \mu \mathrm{L} \mathrm{T} 4$ polynucleotide kinase (PNK) (Boehringer Mannheim, Indianapolis, Ind.), $5 \mu \mathrm{L}$ $(\approx 50 \mu \mathrm{ci}) \gamma^{32} \mathrm{P}$ dATP, $2 \mu \mathrm{L} 10 \times$ PNK buffer, and $7 \mu \mathrm{L}$ distilled water. The solution was incubated at $37^{\circ} \mathrm{C}$ for $30 \mathrm{~min}$. Inactivation of T4 PNK was by heating at $65^{\circ} \mathrm{C}$ for $10 \mathrm{~min}$. Volume was brought to $100 \mu \mathrm{L}$ with $1 \times \mathrm{TE}(\mathrm{pH} 7.6)$. Unincorporated dATP was removed using a G-50 Sephadex column.

Polymerase chain Reaction and Cloning. Genomic DNA was used for amplification with degenerate primers $\mathrm{Cu} 1$ and $\mathrm{Cu} 2$. Each $25 \mu \mathrm{L}$ reaction contained $100 \mathrm{ng}$ of genomic DNA template, 1.25 units of Taq DNA polymerase (Sigma, St Louis, Mo.), 150 ng of each of two primers $\mathrm{Cu} 1$ and $\mathrm{Cu} 2,10 \mu \mathrm{mol} d N T P s$ and PCR buffer (Sigma) to a final concentration of $10 \mathrm{~mm}$ Tris- $\mathrm{HCl}, 1.5 \mathrm{~mm}$ $\mathrm{MgCl}_{2}, 50 \mathrm{~mm} \mathrm{KCl}$ with a $\mathrm{pH}$ of 8.3. Polymerase chain reactions were initiated by a denaturation step at $94^{\circ} \mathrm{C}$ for $2 \mathrm{~min}$, then the reaction was subjected to 30 cycles of $94^{\circ} \mathrm{C}$ for $1 \mathrm{~min}, 58^{\circ} \mathrm{C}$ for $1 \mathrm{~min}$, and $72^{\circ} \mathrm{C}$ for $1 \mathrm{~min}$ with a final elongation step of $10 \mathrm{~min}$ at $72^{\circ} \mathrm{C}$. Amplification products were resolved by electrophoresis on a $0.8 \%$ agarose gel with ethidium bromide in TAE buffer and visualized under UV illumination.

Fresh PCR products derived from genomic DNA with primers $\mathrm{Cu} 1$ and $\mathrm{Cu} 2$ that produced a single band in agarose gel electrophoresis were cloned into pCR2.1 vector with the Original TA Cloning Kit (Invitrogen Corp., Carlsbad, Calif.) using the manufacturer's recommended protocol. After ligation, INVaF' Escherichia coli cells (Invitrogen Corp.) were transformed with the plasmid, and colonies containing plasmid with insert were selected on plates with LB kanamycin medium containing 50 $\mu \mathrm{g} \cdot \mathrm{mL}^{-1}$ kanamycin and X-Gal. Forty clones were amplified by PCR with primers $\mathrm{Cu} 1$ and $\mathrm{Cu} 2$ to check ligation results. For colony PCR reaction, the bacterial colony was picked by a toothpick and put into the reaction tube as template DNA. The reaction condition is same as mentioned above for genomic DNA. The PCR products were electrophoresed on a $0.8 \%$ agarose gel to visualize ligation products.

Restriction anAlysis. Polymerase chain reaction products derived from 39 inserted clones were digested by four restriction enzymes Alu I, Rsa I, Sau3 AI, and Hae III (GIBCO/BRL, Grand Island, N.Y.) with 4 bp recognition sites (Table 1) to distinguish different clones, and $5 \mu \mathrm{L}$ of PCR products were digested with 5 unit restriction enzyme, respectively. The digested products were subjected to electrophoresis on a $0.8 \%$ agarose gel.

SSCP ANALYSIS. The protocol for SSCP analysis was based on the methods described by Lee et al. (1992) with some modifications. To carry out SSCP gel electrophoresis, $6 \%$ polyacrylamide gels (49 acrylamide : 1 bisacrylamide) were made up in $0.5 \times \mathrm{TBE}$ buffer containing 5\% glycerol. Bacterial colonies or $100 \mathrm{ng}$ genomic DNA were used as template DNA for the labeling PCR.
The PCR reaction with two labeled primers $\mathrm{Cu} 1$ and $\mathrm{Cu} 2$ was set as follows: $25 \mu \mathrm{L}$ volume containing $37.5 \mathrm{ng}$ labeled $\mathrm{Cu} 1$ and $\mathrm{Cu} 2$ primers, same amount of dNTPs, Taq polymerase and PCR buffer as mentioned above for genomic PCR. Reaction conditions were the same as above. Heat-denatured PCR samples $(1 \mu \mathrm{L})$ mixed with $2 \mu \mathrm{L}$ sequence stop solution containing formamide (United States Biochemical, Cleveland, Ohio) were applied to the gel and electrophoresis was carried out at a constant power of $2 \mathrm{~W}$ for 20 hours. The gel was kept at constant room temperature. At the end of electrophoresis, the gel was transferred onto a sheet of Whatman $3 \mathrm{MM}$ paper and vacuum dried at $80^{\circ} \mathrm{C}$ for $1.5 \mathrm{~h}$. Autoradiography was carried out overnight at $-80^{\circ} \mathrm{C}$ using Kodak diagnostic film (Rochester, N.Y.).

SEQUENCE AND ANALYSIS. The high quality plasmid DNA of each group of clones were prepared using the QIAprep miniprep kit (QIAGEN, Valencia, Calif.) using the manufacturer's recommended protocol. The clones were sequenced as ds DNA using Perkin-Elmer ABI prism 377 sequenator with analysis version 2.1.1. The alignment with other reported aquaporin genes was performed with the FASTA (Pearson and Miller, 1992) or Blast (Altschul et al., 1990) programs (GenBank).

\section{Results and Discussion}

PCR PRODUCTS AND ClONing. Total DNA of cucumber was amplified by PCR using two degenerate primers $\mathrm{Cu} 1$ and $\mathrm{Cu} 2$. After PCR products were resolved on a $0.8 \%$ agarose gel, only one band of $\approx 500$ bp was observed, while no band was observed in the control having no template DNA. Compared with the two well-conserved NPA motif genomic sequences for aquaporin genes cloned from tobacco and Arabidopsis thaliana (Höfte et al., 1992; Yamamoto et al., 1991), this band is shorter than those of the tobacco aquaporin gene TobRB7 ( $\approx 660$ bp including a 284 bp intron) (Yamamoto et al., 1991) as well as that of the Arabidopsis aquaporin gene $\alpha-T I P(\approx 580$ bp with one 120 bp intron) (Höfte et al., 1992). It is similar in size to the other Arabidopsis aquaporin gene $\gamma$-TIP ( $\approx 450$ bp with a 91 bp intron) (Höfte et al., 1992).

The fresh PCR products were cloned into the pCR2.1 vector. Forty white colonies (designated as C1-1 to C1-40) were taken at random to do $\mathrm{PCR}$ with $\mathrm{Cu} 1$ and $\mathrm{Cu} 2$ primers to test the insertion. The results indicated that 39 out of 40 clones (all except C1-39) had a PCR product of $\approx 500 \mathrm{bp}$.

RESTRICTION ENZYME ANALYSIS. Restriction analysis of PCR products showed that all four enzymes (Alu I, Rsa I, Sau3 AI, and Hae III) could be employed to detect differences among 39 samples (Table 1). When PCR products of 39 clones were digested by $R$ sa I, 35 clones had the same restriction band pattern.

Table 1. The polymorphism of clones identified by the restriction enzyme analysis. ${ }^{\mathrm{z}}$

\begin{tabular}{lclc}
\hline & $\begin{array}{c}\text { Tested } \\
\text { clones } \\
\text { (no.) }\end{array}$ & $\begin{array}{l}\text { Clones with } \\
\text { different restriction } \\
\text { polymorphisms from each major group }\end{array}$ & $\begin{array}{c}\text { Potential } \\
\text { groups } \\
\text { (no.) }\end{array}$ \\
\hline Rsa I & 39 & $\mathrm{C} 1-16^{\mathrm{y}}, \mathrm{C} 1-20, \mathrm{C} 1-35(\mathrm{C} 1-40)$ & 4 \\
Alu I & 39 & $\mathrm{C} 1-16^{\mathrm{y}}, \mathrm{C} 1-1, \mathrm{C} 1-35(\mathrm{C} 1-40)$ & 4 \\
Sau 3AI & 39 & $\mathrm{C} 1-16, \mathrm{C} 1-20, \mathrm{C} 1-35(\mathrm{C} 1-40)$ & 4 \\
Hae III & 39 & $\mathrm{C} 1-16, \mathrm{C} 1-20, \mathrm{C} 1-35(\mathrm{C} 1-40)$ & 4 \\
Total & 39 & $\mathrm{C} 1-1, \mathrm{C} 1-16, \mathrm{C} 1-20, \mathrm{C} 1-35(\mathrm{C} 1-40)$ & 5
\end{tabular}

${ }^{\mathrm{z}}$ Samples inside parentheses had the same restriction polymorphism as samples outside parentheses.

'Undigested sample. 
The band pattern of clone C1-20 was different from the others. Clones C1-35 and C1-40 were the same, but were different from the other clones. Clone C1-16 was undigested, possibly because there was no recognition site between the cloned regions. When Alu I was used, 35 clones (including C1-20) had the same restriction band pattern, and clones $\mathrm{C} 1-35$ and $\mathrm{C} 1-40$ were the same as each other but different from the others. Clone $\mathrm{C} 1-1$ was different from all of the others. Clone $\mathrm{C} 1-16$ was still undigested. For Sau 3AI and Hae III, 35 out of 39 clones had the same restriction band patterns, clone $\mathrm{C} 1-16$ was digested and different from the others. Clone $\mathrm{C} 1-20$ was different from the others. Clones C1-35 and C1-40 were the same as each other but different from the others.

We concluded that clones $\mathrm{C} 1-1, \mathrm{C} 1-16$, and $\mathrm{C} 1-20$ were different from each other and the other clones. Clones $\mathrm{C} 1-35$ and C1-40 were the same as each other but different from the others. The remaining 34 clones were the same. Results of the restriction analysis suggested that the 39 clones could be divided into five groups, and that four potentially homologous aquaporin gene members were identified by this analysis. Our results were similar to a previous report that more member genes could be obtained by digesting clones with restriction enzymes (Preston, 1993). Clone C1-13 from the majority group, along with four different clones (C1-16, C1-20, C1-35 and C1-1) were designated CRB1, CRB2, CRB3, CRB4 and CRB5 for further study.

SSCP ANALYSIS. We tested the ability of SSCP analysis to

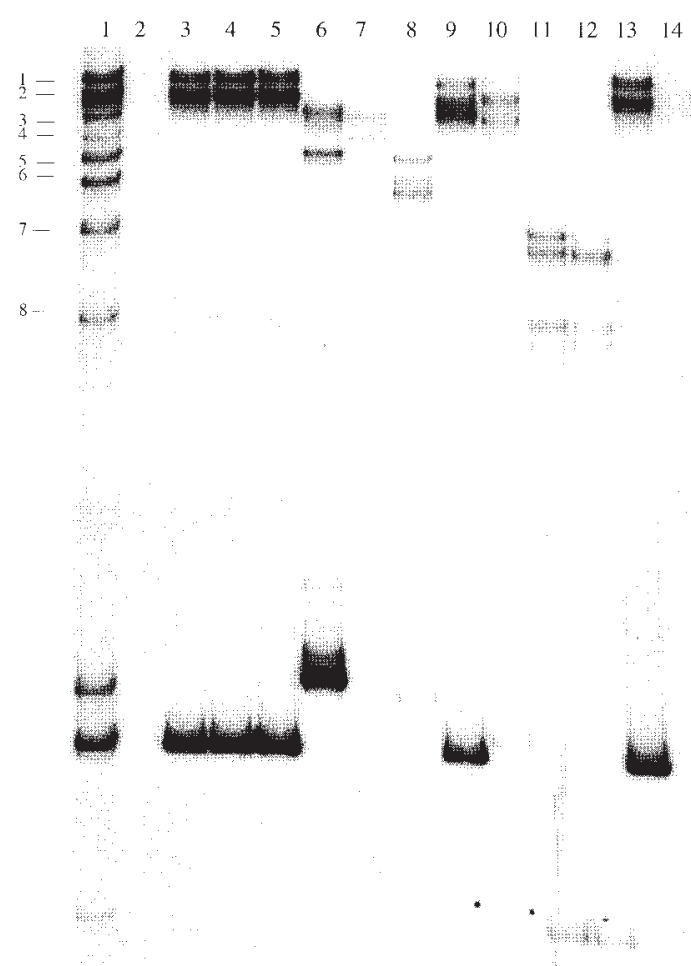

\footnotetext{
Fig. 1. SSCP bands of cucumber genomic DNA and different clone PCR products amplified by two degenerate primers $\mathrm{Cu} 1$ and $\mathrm{Cu} 2$. Lane $1=$ genomic DNA; lane 2 $=$ without template DNA as control; lane $3=\mathrm{CRB} 1$; lane $4=\mathrm{C} 2-5$; lane $5=\mathrm{C} 2-2$; lane $6=\mathrm{CRB} 2$; lanc $7=\mathrm{CRB} 3$; lane $8=\mathrm{CRB} 4$; lane $9=\mathrm{CRB} 6$; lane $10=\mathrm{CRB} 8$; lane I1 = CRB9; lane $12=\mathrm{CRB} 10 ;$ lane $13=\mathrm{C} 2-1$; lane $14=\mathrm{CRB} 5$.
}

Fig. 1. SSCP bands of cucumber genomic DNA and different clone PCR products amplified by two degenerate primers $\mathrm{Cu} 1$ and $\mathrm{Cu} 2$. Lane $1=$ genomic DNA; lane 2 = without template DNA as control; lane $3=\mathrm{CRB} 1$; lane $4=\mathrm{C} 2-5$; lane 5 = C2-2; lane 6 = CRB2; lane 7 = CRB3; lane 8 = CRB4; lane 9=CRB6; lane $10=\mathrm{CRB} 8$; lane 11 = CRB9; lane 12=CRB10; lane 13=C2-1; lane 14=CRB5. distinguish different clones. Seven clones CRB1 to CRB5 and two more samples (C1-5 and $\mathrm{C} 1-8)$ from the remaining majority group were subjected to SSCP analysis. The results showed that SSCP analysis was highly sensitive in distinguishing differences among clones. The band patterns of the five clones CRB1 to CRB5 were different on the SSCP gel, while they could not be distinguished by normal agarose gel electrophoresis. The SSCP bands of CRB1, CRB2, CRB3, CRB4 and CRB5 were similar to lanes 3, 6, 7, 8, and 14 in Fig. 1. Clone CRB4 migrated faster than the other four, followed by Clone CRB3, and then CRB2. Three clones (C1-5, C1-8 and CRB1) from the remaining group characterized by restriction analysis produced monomorphic SSCP bands (data not shown). Thus, the results suggested that SSCP gel analysis could distinguish differences among clones.

Generally, two single-strand DNAs should produce only two conformation polymorphisms, and yield two SSCP bands. However, some electrophoretic profiles showed three or four instead of two bands. This might be due to the presence of two stable conformations for one of the bands (Hayashi, 1991), or to an excess of primers that might bind to the DNA strands and form a detectable subspecies (Cai and Touitou, 1993). These types of artifacts can be avoided by removing the oligonucleotides from the PCR product (Fujita and Silver, 1994) or by diluting it (Rubio et al., 1996).

For testing the detection efficiency of SSCP analysis, 21 untested white clones derived from cloning of PCR products were selected and designated as $\mathrm{C} 2-1$ to $\mathrm{C} 2-21$ for analysis. The five different clones CRB1 to CRB5 that had been confirmed by the restriction enzyme and SSCP analysis were analyzed again to determine the reproducibility of SSCP bands. Meanwhile, PCR products of cucumber genomic DNA that were amplified by two degenerate primers ( $\mathrm{Cu} 1$ and $\mathrm{Cu} 2)$ were analyzed together with the 21 new clones.

The results indicated that the SSCP band patterns of five different groups were repeatable. The five different clones had different band patterns as observed before. Our work further confirmed the previous report that the resulting SSCP pattern was highly reproducible when conditions were held constant (Fan et al., 1993). Among the 21 newly tested clones, there were 8 SSCP band patterns. Clone $\mathrm{C} 2-21$ was different from the other 20 clones, but it had the same pattern as clone CRB4 that already has been observed. Clones C2-3, C2-12, and C2-19 were the same as each other and the same as clone CRB3. The band patterns of clones C2-4, C2-6, C2-14, C2-16, and C2-18 were different from each other, and different from those of the previously observed 5 clones. The remaining 12 clones were the same as each other and the same as the previously observed majority group (data not shown). Clones C2-4, C2-6, C2-14, C2-16, and C2-18 were designated as CRB6, CRB7, CRB8, CRB9, and CRB10. Band patterns of CRB6, CRB8, CRB9, and CRB10 were similar to lanes 9 through 12 of Fig. 1. The CRB9 and CRB10 clones migrated rapidly on the SSCP gel, and they appeared to have small fragments. Clone CRB7 migrated slowly on the gel, and there were two separate bands on top of the SSCP gel (data not shown). Only the band patterns of CRB2 and CRB5 were not observed in the new sample population of 21 clones. From the above observation, 8 different clones, including 5 new clones, were obtained in one SSCP gel containing 21 clone samples, suggesting that SSCP analysis can distinguish among clones with great sensitivity.

Only one band of $\approx 500 \mathrm{bp}$ was observed when the PCR products of cucumber genomic DNA using degenerate primers 
were electrophoresed in the agarose gel. However, 8 bands were separated when they were analyzed by an SSCP gel, and all 8 had corresponding bands from different clones. Also, one or all SSCP bands of 10 different clones except CRB7 had corresponding bands from genomic PCR products. It appears that all of the different fragments of genomic PCR products that were amplified by the two degenerate primers have been subcloned.

The advantage of SSCP analysis with genomic PCR products is that it can provide relevant information on the number of member genes that are amplified by degenerate primers. Theoretically, genomic PCR products that were amplified by the degenerate primers should contain many different fragments representing different member genes. These different fragments have a different single strand conformation and will produce polymorphism on the SSCP gel. Thus, while different clones were analyzed by SSCP, the band pattern of different clones should have corresponding bands from genomic DNA SSCP. By comparing SSCP band patterns of genomic PCR products with SSCP band patterns of clones, we can get a rough identification of the uncloned members. In our study, all 8 bands from genomic DNA SSCP had corresponding bands from cloned fragments. If some SSCP bands of genomic DNA PCR products do not have corresponding bands from cloned fragments, this indicates that some members may not yet have been cloned. To get these uncloned members, additional clones should be analyzed with SSCP until the corresponding band is cloned. Alternatively, the uncloned band from SSCP gel can be cut, reamplified and cloned, as suggested by Slabaugh et al. (1997).
To demonstrate the results of the SSCP analysis, cucumber genomic DNA and the 9 clones representing 9 groups (except CRB7, which had an unexpectedly large size) were re-amplified with two end-labeled degenerate primers $\mathrm{Cu} 1$ and $\mathrm{Cu} 2$ and rerun on the SSCP gel. Three additional clones (C2-1, C2-2, and C2-5) from the largest group were added on lanes 13, 5 and 4 to control two sides of the gel. The representative results of SSCP analysis of 12 partial aquaporin member genes and genomic DNA PCR products are shown in Fig. 1. The SSCP band patterns of each sample were similar to those in the previous tests. The SSCP results of genomic DNA PCR products had 8 bands in the SSCP gel. The SSCP band patterns of CRB1, CRB2, CRB3, CRB4, CRB5, CRB6, CRB8, CRB9 and CRB10 were different. The CRB9 and CRB10 clones migrated rapidly on the gel. Four clones (CRB1, C2-1, C2-2, and C2-5) from the same group had the same SSCP band patterns.

Sequence Results AND anAlysis. All ten different clones CRB1 to CRB10 were subjected to sequencing. The fragment of CRB7 was large and atypical, and since there was no relevant band from genomic DNA PCR products, we decided to sequence it for comparison. All ten clones were sequenced as ds-DNA using a Perkin-Elmer ABI Prism 377 sequenator. They were subjected to BLAST search with and without primers. Search results revealed that nine of the ten clones were homologues of aquaporin genes (data not shown); only CRB7 was a homologue of the $16 \mathrm{~S}$ ribosomal RNA gene. CRB7 may have been misamplified and cloned. Among nine analyzed fragments that were amplified by degenerate oligonucleotide primers, four of
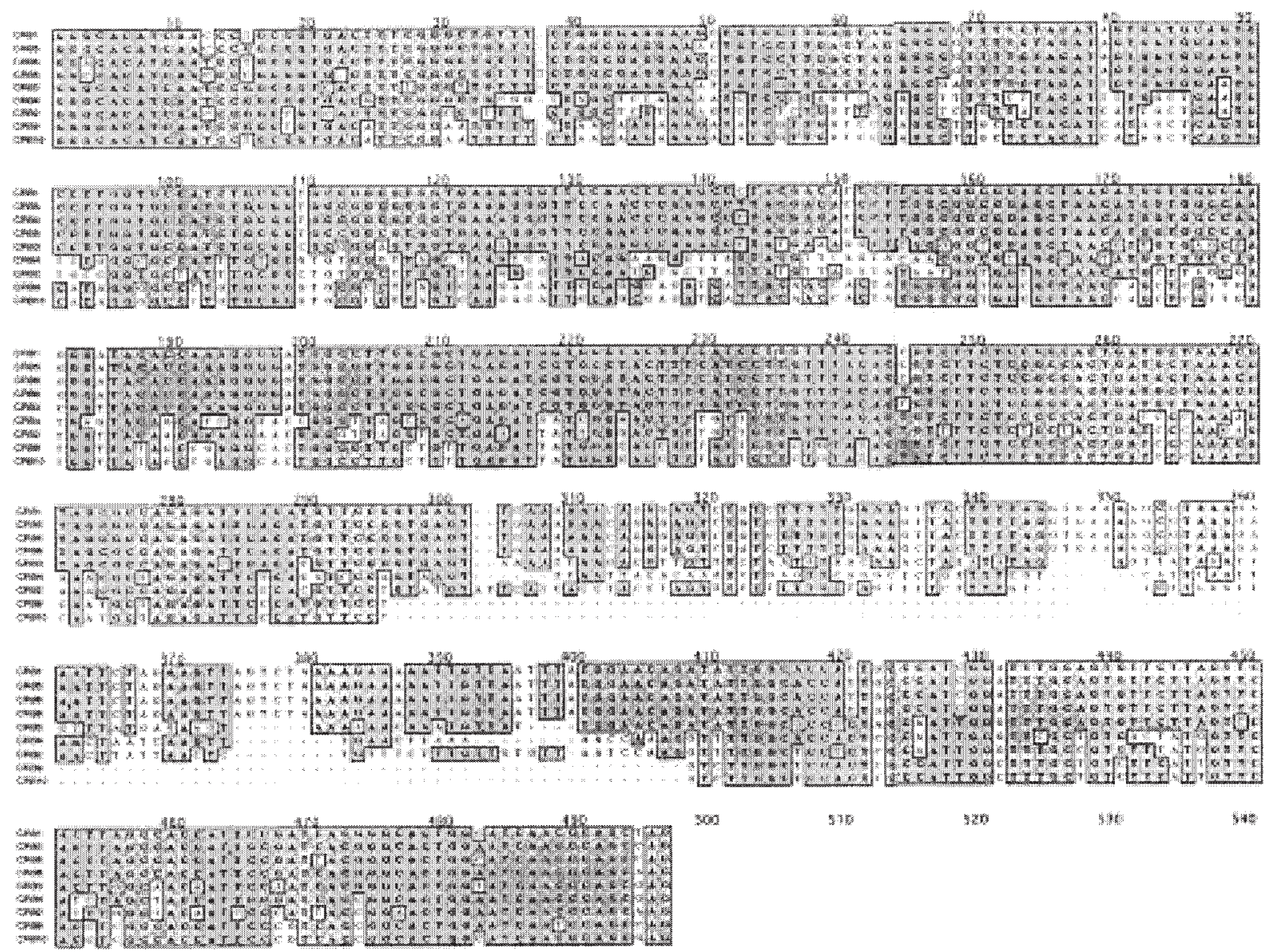

wa

sis

was

Wh

औ*

Fig. 2. The nucleotide sequence alignment of nine cucumber aquaporin homologue fragments amplified by two degenerate primers $\mathrm{Cu} 1$ and $\mathrm{Cu} 2$. Identical nucleotides are highlighted with black boxes; the nucleotides that are missing are indicated by the "-" symbol. 
them (CRB1, CRB5, CRB6, and CRB8) had the same molecular size (493 bp), three of them (CRB2, CRB3, and CRB4) had smaller molecular sizes $(478,479$, and 466 bp), and CRB9 and CRB10 were the same size (383 bp), but smaller than the other seven.

The nine DNA sequences were aligned as showed in Fig. 2 after spreading the sequences in the missing nucleotides. Comparing the nucleotide sequences, the nine clones were different from each other in sequence, even though some of them had the same molecular size. Some small differences between two sequences were observed. There were only 2, 2, 5, 4, 5, 7, and 1 bp differences respectively in sequences without primer regions, and $5,5,9,8,8,12$, and 6 bp differences respectively in sequences with primer regions between the pairs CRB1/CRB5, CRB1/ CRB6, CRB1/CRB8, CRB5/CRB6, CRB5/CRB8, CRB6/CRB8, and CRB9/CRB10.

Sequencing results showed that the fragments that were amplified by degenerate primers based on a highly conserved amino acid sequence had the same or similar molecular size. Most clones in our experiment belonged to the majority group according to SSCP analysis. They were the same as CRB1 with $493 \mathrm{bp}$ molecular sizes. Moreover, three (CRB5, CRB6, and CRB8) out of the nine groups had the same molecular size as CRB1, and the other three groups (CRB2, CRB3, and CRB4) had a size similar to CRB1. Only CRB9 and CRB10 were 110 bp shorter than that of the majority group (CRB1). This means that most initial PCR products of genomic DNA amplified by degenerate primers $\mathrm{Cu} 1$ and $\mathrm{Cu} 2$ had the same or similar molecular size. When the PCR products were run on an agarose gel, they could not be separated from each other owing to their similar molecular size or because they were hidden by majority products, as in the case of CRB 9 and CRB10.

From nucleotide sequences along with SSCP analysis, we have found that SSCP analysis can distinguish 6 to $17 \mathrm{bp}$ differences in sequences with primer ends even if sequences have the similar or same size. However, they would not be distinguishable from each other using agarose gel or restriction enzyme analysis because of similar molecular size and only small differences in base pair number.

By comparing the nine genomic DNA clone sequences with the cucumber aquaporin cDNA sequence (data not shown) amplified by RT-PCR with two degenerate primers $\mathrm{Cu} 1$ and $\mathrm{Cu} 2$, we found that seven fragments (CRB1, CRB2, CRB3, CRB4, CRB5, CRB6, and CRB8) had an intron between two well-conserved NPA motif regions, and they share identical intron positions localized in connecting loop C. Most characterized plant plasma membrane intrinsic protein members also share that intron position (Johanson et al., 2001). The CRB9 and CRB10 clones were intronless in this region. The CRB10 and CRB9 clones do not have any intron, but have same 124 putative amino acids in the NPA to NPA repeated region with the other 7 fragments. The CRB9 and CRB10 clones are highly homologous to CRB4 and $\mathrm{CRB} 2$, which possess one intron in the NPA repeated region. This suggests that CRB9 and CRB10 evolved with loss of introns. Intron deletion has been reported to occur often during evolution, and may be associated with genome slimming (Petrov et al. 1996).

It is important to clone and characterize many member genes in a family to provide maximum information for the understanding of their function and evolutionary relationship with each family member. Therefore, an efficient procedure for cloning member genes will be useful for the study of gene families.
However, the question arises as to whether the fragments with 1 to $7 \mathrm{bp}$ difference in sequences without primer end regions and 6 to $17 \mathrm{bp}$ differences in sequences with primer ends that were cloned by the PCR-based SSCP analysis are really different gene fragments or just the results of misamplification or sequencing error of the same gene.

A precise comparison of the nucleotides for each pair of gene fragments indicated that they were really different sequences. For example, one pair of gene fragments differing at one base pair was localized to the 39th nucleotide position between CRB9 (thymine ' $T$ ') and CRB10 (cytosine ' $C$ '). The nucleotide of the 39th position of CRB4 had its ' $T$ ' at the same position as that of CRB9. The CRB1, CRB2, CRB3, CRB5, CRB6, and CRB8 clones had their ' $C$ ' at the same position as that of CRB10. The remaining pair of gene fragments, with two to seven base pairs different, was confirmed by finding identical nucleotides from other homologous genes at that position. According to sequence information of nine fragments, nine different pairs of primers were designed to re-amplify each specific fragment from the cucumber genome. Results showed that all pairs of primers could produce predicted PCR bands with cucumber genomic DNAs. Owing to functional importance, a large number of aquaporin genes have been cloned and characterized in animals, plants and microorganisms. Members of the aquaporin family are highly conserved from bacteria to mammals all of which have similar sequences (Johanson et al., 2001). Plant aquaporin gene families with many members and one or several base pairs difference between some members were also well documented in Arabidopsis (Johanson et al., 2001) and maize (Zea mays Bonaf.) (Chaumont et al., 2001). Nine fragments might be real different gene fragments. These nine fragments allow us to identify a root specific aquaporin gene and study phylogenetic relationships of cucumber aquaporin family.

\section{Literature Cited}

Agre, P., S. Sasaki, and M.J. Chrispeels. 1993. Aquaporins: A family of water channel proteins. Amer. J. Physiol. 265:F461.

Altschul, S.F., W. Gish, W. Miller, E.W. Myers, and D.J. Lipman. 1990. Basic local alignment search tool. J. Mol. Biol. 215:403-410.

Cai, Q.Q. and I. Touitou. 1993. Excess PCR primers may dramatically affect SSCP efficiency. Nucleic Acids Res. 21:3909-3910.

Chaumont, F., F. Barrieu, E. Wojcik, M.J. Chrispeels, and R. Jung. 2001. Aquaporins constitutes a large and highly divergent protein family in maize. Plant Physiol. 125:1206-1215.

Fan, E., D.B. Levin, B.W. Glickman, and D.M. Logan. 1993. Limitations in the use of SSCP analysis. Mut. Res. 288:85-92.

Fujita, K. and J. Silver. 1994. Single-strand conformational polymorphism. PCR Meth. Appl. 4:137-140.

Hagiwara, K., A.A.H.Freeman, M.G. McMenamin, and C.C. Harris. 1998. Screening cloned PCR fragments by restriction endonuclease fingerprinting to obtain wild-type sequences. BioTechniques 25:554-558.

Hayashi, K. 1991. PCR-SSCP: A simple and sensitive method for detection of mutations in the genomic DNA. PCR Meth. Appl. 1:3438 .

Hayashi, K. 1992. PCR-SSCP: A method for detection of mutations. Genet. Anal. Tech. Appl. 3:73-79.

Hedley, P.E., G.C. Machray, H.V. Davies, L. Burch, and R. Waugh. 1994. Potato (Solanum tuberosum ) invertase-encoding cDNAs and their differential expression. Gene 145:211-214.

Höfte, H., L. Hubbard, J. Reizer, D. Ludevid, E.M. Herman, and M.J. Chrispeels. 1992 Vegetative and seed-specific forms of tonoplast intrinsic protein in the vacuolar membrane of Arabidopsis thaliana. Plant Physiol. 99:561-570.

Johanson, U., M. Karlsson, I. Johansson, S. Gustavsson, S. Sjövall, L. Fraysse, A.R. Weig, and P. Kjellbom. 2001. The complete set of genes 
encoding major intrinsic proteins in Arabidopsis provides a framework for a new nomenclature for major intrinsic proteins in plants. Plant Physiol. 126:1358-1369.

Lee, H.H., W.J. Lo, and K.B. Choo. 1992. Mutational analysis by a combined application of the multiple restriction fragment-single strand conformation polymorphism and the direct linear amplification DNA sequencing protocols. Anal. Biochem. 205:289-293.

Orita, M., H. Iwahana, H. Kanazawa, K. Hayashi, and T. Sekiya. 1989a. Detection of polymorphisms of human DNA by gel electrophoresis as single-strand conformation polymorphisms. Proc. Natl. Acad. Sci. USA 86:2766-2770.

Park, J.H. and M.H. Saier, Jr. 1996. Phylogenetic characterization of the MIP family of transmembrane channel proteins. J. Membrane Biol. 153:171-180.

Pearson, W.R. and W. Miller. 1992. Dynamic programming algorithms for biological sequence comparison. Meth. Enzyme 210:575-601.

Peterson, D.S., L.H. Miller, and T.E. Wellems. 1995. Isolation of multiple sequences from the Plasmodium falciparum genome that encode conserved domains homologous to those in erythrocyte-binding proteins. Proc. Natl. Acad. Sci. USA 92:7100-7104.

Petrov D.A., E.R. Lozovskaya, and D.L. Hartl. 1996. High intrinsic: rate of DNA loss in Drosophila. Nature 384:346-349.
Preston, G.W. 1993. Use of degenerate oligonucleotide primers and the polymerase chain reaction to clone gene family members, p. 317-337. In: B.A White (ed.). Methods in Molecular Biology. vol. 15. PCR protocols: Current Methods and Applications. Humana, Totoma, N.J. Rubio, L., M.A. Ayllon, J. Guerri, H. Pappu, C. Niblett, and P. Moreno. 1996. Differentiation of citrus tristeza closterovirus (CTV) isolates by single-strand conformation polymorphism analysis of the coat protein gene. Ann. Appl. Biol. 129:479-489.

Sekiya, T. 1993. Detection of mutant sequences by single-strand conformation polymorphism analysis. Mut. Res. 288:79-83.

Slabaugh, M.B., G.M. Huestis, J. Leonard, J.L. Holloway, C. Rosato, V. Hongtrakul, N. Martini, R. Toepfer, M. Voetz, J. Schell, and S.J. Knapp. 1997. Sequence-based genetic markers for genes and gene families: Single-strand conformational polymorphisms for the fatty acid synthesis genes of Cuphea. Theor. Appl. Genet. 94:400-408.

Takumi, T. and H.F. Lodish. 1994. Rapid cDNA cloning by PCR screening. BioTechniques 17:443-444.

Yamamoto, Y.T., C.G. Taylor, G.N Acedo, C.L. Cheng, and M.A. Conkling. 1991. Characterization of cis-acting sequences regulating root-specific gene expression in Tobacco. Plant Cell 3:371-382.

You, T.H. and R.L. Scholl. 1998. PCR amplification of cDNA libraries for cloning and screening. BioTechniques 24:574-575. 